\title{
Emergent and non-emergent species of harpacticoid copepods can be recognized morphologically
}

\author{
David Thistle*, Linda Sedlacek \\ Department of Oceanography, Florida State University, Tallahassee, Florida 32306-4320, USA
}

\begin{abstract}
Emergence - the active movement of benthic organisms into the water column and back - has consequences for many ecological processes, e.g. benthopelagic coupling. Harpacticoid copepods are conspicuous emergers, but technical challenges have made it difficult to determine which species emerge, impeding the study of the ecology and evolution of the phenomenon. We examined data on harpacticoid emergence from 2 sandy, subtidal sites ( $20 \mathrm{~m}$ deep) in the northern Gulf of Mexico and found 6 species that always emerged and 2 species that never emerged. An examination of the locomotor appendages revealed that the number of segments in the endopods of pereiopods 2-4 and the number of setae and spines on the distal exopod segments of pereiopods 2-4 can be used to distinguish emergers from non-emergers. We then successfully used these characters to predict the behavior of 3 additional species. Certain morphological differences may therefore allow differentiation of emergers from non-emergers.
\end{abstract}

KEY WORDS: Emergence · Harpacticoid copepods - Continental shelf $\cdot$ Benthopelagic coupling Resale or republication not permitted without written consent of the publisher

\section{INTRODUCTION}

The active movement of individual benthic animals from the seabed into the water column and back, often with a diel periodicity, is termed 'emergence' (see review by Mees \& Jones 1997). Emergers include species of polychaetes, turbellarians, amphipods, cumaceans, and harpacticoid copepods. Their emergence has importance for many phenomena, including benthopelagic coupling (Marcus \& Boero 1998).

Harpacticoid copepods are small crustaceans (body length $<1.0 \mathrm{~mm})$ that occur in large numbers $\left(10^{5}\right.$ to $10^{6}$ ind. $\mathrm{m}^{-2}$ ) in marine sediments (Hicks \& Coull 1983). In some locations, a substantial portion of the population emerges every 24 h (Walters \& Bell 1986, 1994, Arlt 1988, Buffan-Dubau \& Castel 1996, Thistle 2003). Harpacticoid emergence has been studied extensively (Fleeger et al. 1984, Hicks 1986, Walters \& Bell 1986, Armonies 1988, Buffan-Dubau \& Castel 1996) and has been important in attempts to develop generalizations about emergence (see review by Palmer 1988, Armonies 1989, Thistle 2003).
What appear to be emergent harpacticoids have been found in such varied environments as sandy beaches, seagrass meadows, mudflats, coral reefs, and the continental shelf; therefore, harpacticoid emergence might be widespread. At the same time, few studies have been carried out, so the behavior of a species is unlikely to be known a priori. For many purposes (e.g. prediction of habitat use, Bell et al. 1987), the ability to identify species that emerge without observation of their behavior would be useful. Also, the discovery of characteristics common to emergers could help in studies of the ecology and evolution of the behavior.

Bell et al. (1987) searched for morphological similarities among harpacticoid emergers, but their task was made more difficult as the data available to them did not separate experimentally induced from true emergence. That is, harpacticoid emergence had been investigated primarily with traps sealed to the seabed (Hicks 1986, Walters \& Bell 1986). Such traps created still water, which was suspected to stimulate emergence (Palmer 1988). Recent field work has shown that this concern was well founded (Thistle 2003). As a 
consequence, Bell et al. (1987) may have inadvertently considered some animals to be emergers that were not, making it more difficult to identify characters that united among the group.

To circumvent this problem, we assembled data that allowed us to separate species that emerged artifactually from species that emerged naturally. Following Remane (1952) and Noodt (1971), we asked (1) whether certain characters united emergers, (2) whether certain characters united non-emergers, and (3) whether certain characters differentiated the 2 groups.

\section{MATERIALS AND METHODS}

Study sites. We used data from Thistle (2003) and L. Sedlacek \& D. Thistle (unpubl.). Thistle's site was a $3 \times 10 \mathrm{~m}$ plot at $18 \mathrm{~m}$ depth in the northern Gulf of Mexico $\left(29^{\circ} 40.63^{\prime} \mathrm{N}, 84^{\circ} 22.80^{\prime} \mathrm{W}\right.$; Thistle 2003). The seabed was an unvegetated, moderately sorted, medium sand with $<1 \%$ silt and clay by weight (see Thistle et al. 1995, their Table 1). Sedlacek \& Thistle's site was a $1.5 \times 60 \mathrm{~m}$ plot at $20 \mathrm{~m}$ depth $\left(30^{\circ} 22.65^{\prime} \mathrm{N}\right.$, $86^{\circ} 38.69^{\prime} \mathrm{W}$ ) about $230 \mathrm{~km}$ west of Thistle's. Seabed properties were similar to those at Thistle's (2003) site.

Sampling. Thistle (2003) and L. Sedlacek \& D. Thistle (unpubl.) used the same inverted-funnel traps (see Thistle 2003, his Fig. 1) to collect emerging individuals. Each trap consisted of a cylindrical collecting chamber whose transparent walls and funnel minimized light attenuation, which might alter the behavior of the harpacticoids. The sides of the funnel sloped at $60^{\circ}$. Its openings were $1.5 \mathrm{~cm}$ and $10 \mathrm{~cm}$ in diameter. The collecting chambers were mounted in 2 ways. In a 'base trap', a collecting chamber was attached to a transparent cylindrical base after the base had been inserted into the sediment. A stabilizing ring limited the penetration of the base into the sediment to hold the lower opening of the funnel $4.5 \mathrm{~cm}$ above the seabed. Each base had 2 rows of 18 ports of $1.1 \mathrm{~cm}$ diameter that were covered with $50-\mu \mathrm{m}$-aperture mesh to allow some exchange of water while retaining the harpacticoids. One row was centered $1.6 \mathrm{~cm}$ above the sediment surface, and one was centered $2.7 \mathrm{~cm}$ below the sediment surface. In a 'leg trap', a collecting chamber was placed on a tripod that held the lower opening of the funnel $4.5 \mathrm{~cm}$ above the seabed, allowing more or less free water movement beneath the chamber. In both cases, the entrance to the collecting chamber was $15 \mathrm{~cm}$ above the sediment. Before deployment, each collecting chamber was filled with $50-\mu \mathrm{m}$-filtered seawater obtained from $\sim 50 \mathrm{~cm}$ above bottom at the study site. The smaller funnel opening was sealed with a stopper that prevented exchange during transit to the seabed. The stopper was removed when the trap was ready to be placed on its base or tripod.

Thistle (2003) tested for differences in emergence between 2 seasons. Traps were set out in a blocked design; 1 base trap and 1 leg trap constituted a block. On a given day, 3 blocks were deployed. After $\sim 24 \mathrm{~h}$, a SCUBA diver inserted a stopper into the smaller funnel opening of the collecting chamber of each leg trap to close it in situ. The collecting chamber of each base trap was released from the base and raised $\sim 20 \mathrm{~cm}$ to allow the stopper to be inserted. To estimate the number of harpacticoids remaining in the section of seabed enclosed, a diver took a $15.5-\mathrm{cm}^{2}$-diameter core from the center of the area enclosed by the base before the base was removed from the sediment (see Walters \& Bell 1986).

On deck, the water in each collecting chamber was sieved on $50-\mu \mathrm{m}$-aperture mesh. Each core was mounted on a precision extruder (Fuller \& Butman 1988). The water overlying the core was removed and sieved $(50-\mu \mathrm{m}$-aperture mesh); the sieve content was added to the 0 to 2-mm-layer sample. The top centimeter was sliced into $2 \mathrm{~mm}$ layers. All samples were preserved in sodium-borate-buffered seawater formaldehyde $(9: 1, \mathrm{v}: \mathrm{v})$.

In the laboratory, the collecting-chamber samples and the sediment samples were stained with rose Bengal (Pfannkuche \& Thiel 1988), and the harpacticoids were removed under a dissection microscope. For collecting-chamber samples, all adult harpacticoids were identified to working species. Because large numbers of harpacticoids were present in the sediment samples, only $50 \%$ of the adult harpacticoids were identified. For each adult, a random-numbers table was consulted. If the digit was odd, the individual was identified; if the digit was even (zero was treated as even), it was not (Walters \& Bell [1986] solved this problem in a similar way). Most of the species encountered have not been formally described.

L. Sedlacek \& D. Thistle (unpubl.) studied emergence from sediment crests and troughs. On successive days during November 1999, SCUBA divers placed traps at randomly assigned locations with the restriction that traps be at least $2.7 \mathrm{~m}$ (10 trap diameters) apart to minimize the possibility of hydrodynamic interference. Each day, SCUBA divers placed 4 traps -2 base traps ( 1 on a crest and 1 in a trough) and 2 leg traps (1 on a crest and 1 in a trough) and recovered them $24 \mathrm{~h}$ later. They used the same traps, trap-handling procedures, and sample-processing procedures as Thistle (2003), except that all adult individuals were identified to working species.

We used the scheme devised by Thistle (2003) to classify the emergence behavior of each species. A species absent from base traps and sediment cores, 
but present in leg traps, was considered planktonic. A species found in only 1 replicate was considered too rare to classify accurately. A species absent from base traps and leg traps but present in sediment cores was classified as a non-emerger. A species present in base traps and leg traps was considered an emerger, whether or not it was present in sediment cores. A species present in base traps, but not in leg traps, was considered to have emerged as an artifact of the experiment. Species absent from base traps but present in leg traps and found in the sediment could not be classified. Of the classified species, we determined which species had been abundant enough to classify in at least 3 of the 4 data sets and had also been classified the same (e.g. as an emerger) in each data set. These species were deemed to have been consistent in their behavior.

Morphological analysis. The one thing that we knew a priori about emergers was that they could swim at least $15 \mathrm{~cm}$ from the seabed, because they were caught in the collecting chambers of emergence traps. We therefore suspected that characters associated with swimming might unite this group. In harpacticoids, pereiopods $2-4$ are the primary locomotor appendages. In swimming harpacticoids, one would expect these appendages to be effective paddles and thus to be relatively large, in contrast with the condition in some harpacticoids, where the numbers of segments and numbers of setae on the swimming legs are reduced (Noodt 1971). In harpacticoids, unreduced pereiopods 2-4 have 3-segmented exopods and endopods and have 7, 8, and 8 setae/spines respectively on the terminal segments of the exopods (Huys \& Boxshall 1991) (Fig. 1). We tabulated these characters for emergers and non-emergers.

To compare our results to those of Bell et al. (1987), we measured the characters that they found to be most informative on each of our species that had consistent behavior. Their characters were (1) the ratio of the length of the first endopodal segment of the first pereiopod to that of the remainder of the endopod, (2) the projected area of the cephalosome in dorsal view, and (3) the length of the antennule of adult females. We measured these characters as illustrated in Bell et al. (1987, their Fig. 1) from camera lucida illustrations of our species.

We also tested the ability of our morphological characters to differentiate emergent and non-emergent species. To do so, we exploited the strict nature of our classification scheme. For example, if a single individual was caught in the base trap and a single individual was caught in the leg trap, the species was classified as an emerger, no matter how many individuals were found in the sediment. This conservatism was necessary because the number of individ-

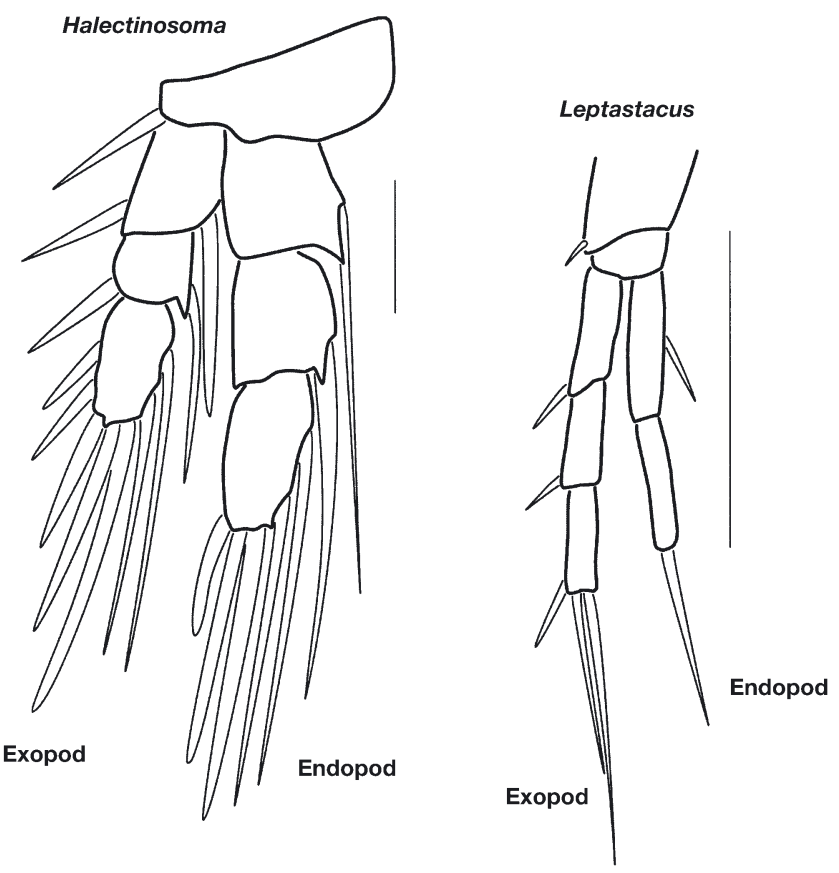

Fig. 1. Sketch of the second pereiopod of Halectinosoma sp., representing the emergers, and Leptastacus cf. coulli, representing the non-emergers, showing the difference in number of endopodal segments and in number of terminal-segment setae of the exopod. Scale lines are $0.05 \mathrm{~mm}$

uals that emerge in $24 \mathrm{~h}$ can be small but consistent for some species (L. Sedlacek \& D. Thistle unpubl.). At the same time, in a scheme so sensitive to single individuals, mistakes in classification were possible. For example, in the process of trap installation or removal, an individual could have been caught where it did not ordinarily occur, or a species could have been rare at the location and time of the sampling, so no individual was available to enter a trap. An inspection of the abundance data revealed that 3 species had not been analyzed because a single observation caused them to be viewed as inconsistent. From the distribution of individuals among base traps, leg traps, and the sediment, we inferred the behavior of each of these species. As a test of the ability of the characters we used to predict species' behavior, we compared the morphologically predicted behavior to that inferred from the abundance data.

\section{RESULTS}

A total of 28 species were examined for consistency of behavior. Of these, 6 species were consistent emergers, and 2 were consistent non-emergers (Table 1). 
Table 1. Selected characters of species that had consistent emergence behavior, showing that non-emergers differed from emergers. P2-P4 end segs = number of segments in the endopods of pereiopods $2-4$ respectively. P2-P4 exp setae $=$ number of setae and spines on the distal exopod segments of pereiopods $2-4$ respectively

\begin{tabular}{|c|c|c|c|c|c|c|c|c|}
\hline Family & Species & Behavior & $\begin{array}{c}\text { P2 } \\
\text { end } \\
\text { segs }\end{array}$ & $\begin{array}{c}\text { P3 } \\
\text { end } \\
\text { segs }\end{array}$ & $\begin{array}{c}\text { P4 } \\
\text { end } \\
\text { segs }\end{array}$ & $\begin{array}{c}\text { P2 } \\
\text { exp } \\
\text { setae }\end{array}$ & $\begin{array}{c}\text { P3 } \\
\text { exp } \\
\text { setae }\end{array}$ & $\begin{array}{c}\text { P4 } \\
\text { exp } \\
\text { setae }\end{array}$ \\
\hline Leptastacidae & Leptastacus cf. coulli & Non-emerger & 2 & 2 & 2 & 3 & 4 & 4 \\
\hline Tetragonicipitidae & Phyllopodopsyllus sp. & Non-emerger & 2 & 2 & 2 & 4 & 4 & 4 \\
\hline Ambunguipedidae & cf. Ambunguipes & Emerger & 3 & 3 & 3 & 7 & 8 & 8 \\
\hline Diosaccidae & Amphiascus cf. varians & Emerger & 3 & 3 & 3 & 7 & 7 & 8 \\
\hline Ectinosomatidae & Halectinosoma sp. & Emerger & 3 & 3 & 3 & 7 & 8 & 7 \\
\hline Ectinosomatidae & Pseudobradya cf. exilis & Emerger & 3 & 3 & 3 & 7 & 8 & 8 \\
\hline Ectinosomatidae & Ectinosoma sp. & Emerger & 3 & 3 & 3 & 7 & 8 & 8 \\
\hline Thalestridae & cf. Dactylopodia & Emerger & 3 & 3 & 3 & 7 & 8 & 7 \\
\hline
\end{tabular}

Table 2. Characters used by Bell et al. (1987), showing that non-emergers differed from emergers in cephalosome area. $\mathrm{N}=$ non-emerger, $\mathrm{E}=$ emerger. $\mathrm{P} 1$ ratio $=$ ratio of the length of the first endopodal segment of pereiopod 1 to the length of the remainder of the endopod. Cephalosome area = projected area of the cephalosome in dorsal view. A1 length = length of the antennule

\begin{tabular}{|lcccc|}
\hline Species & Behavior & $\begin{array}{c}\text { P1 } \\
\text { ratio }\end{array}$ & $\begin{array}{c}\text { Cephalosome } \\
\text { area }\left(\mathrm{mm}^{2}\right)\end{array}$ & $\begin{array}{c}\text { A1 } \\
\text { length (mm) }\end{array}$ \\
\hline Leptastacus cf. coulli & $\mathrm{N}$ & 1.08 & 0.004 & 0.101 \\
Phyllopodopsyllus sp. & $\mathrm{N}$ & 3.50 & 0.007 & 0.089 \\
cf. Ambunguipes & $\mathrm{E}$ & 5.08 & 0.153 & 0.234 \\
Amphiascus cf. varians & $\mathrm{E}$ & 2.14 & 0.013 & 0.112 \\
Ectinosoma sp. & $\mathrm{E}$ & 0.49 & 0.014 & 0.051 \\
cf. Dactylopodia & $\mathrm{E}$ & 6.60 & 0.079 & 0.180 \\
Halectinosoma sp. & $\mathrm{E}$ & 0.38 & 0.050 & 0.080 \\
Pseudobradya cf. exilis & $\mathrm{E}$ & 0.37 & 0.010 & 0.026 \\
\hline
\end{tabular}

those of the non-emergers, but the non-emergers and the emergers did differ in cephalosome area.

The 3 species whose inconsistency of classification turned on a single observation were Bradyellopsis sp., Longipedia sp., and Rhizothrix sp. (Table 3). From an examination of the distribution of abundance among the base trap, leg trap, and sediment samples (Table 3), we inferred that Rhizothrix was a non-emerger and that Bradyellopsis and Longipedia were emergers. The character states of Rhizothrix sp. matched those of the 2 non-emergers (Tables 1 \& 4). The character states of Bradyellopsis

The character states of 6 locomotor-appendage characters distinguished the emergers from the nonemergers (Table 1). For example, the endopods of the second pereiopods of the non-emergers had 2 segments, but those of the emergers had 3. We also compared the groups using Bell et al.'s (1987) characters. Table 2 shows that the values of their pereiopod and antennule characters for the emergers encompassed matched those of the emergers (Tables 1 \& 4). For Longipedia, the number of segments in the endopods of pereiopods 2-4 matched those of the emergers (Tables $1 \& 4$ ), but the numbers of terminal setae on the exopod of pereiopods 2-4 were 6 , 6 , and 5 respectively, lower than those of the emergers but higher than those of non-emergers (Tables 1 \& 4).

Table 3. Species whose inconsistent classifications were caused by single observations, showing the problematic observations (italics). $\mathrm{B}$ = number of individuals collected in base traps. $\mathrm{S}=$ estimated number of individuals in the sediment enclosed by base traps, $\mathrm{L}=$ number of individuals collected in leg traps

\begin{tabular}{|c|c|c|c|c|c|c|c|c|c|c|c|c|}
\hline \multirow[t]{2}{*}{ Species } & \multicolumn{3}{|c|}{ Data set 1} & \multicolumn{3}{|c|}{ Data set 2} & \multicolumn{3}{|c|}{ Data set 3} & \multicolumn{3}{|c|}{ Data set 4} \\
\hline & B & $\mathrm{S}$ & $\mathrm{L}$ & B & $\mathrm{S}$ & $\mathrm{L}$ & B & $\mathrm{S}$ & $\mathrm{L}$ & B & $\mathrm{S}$ & $\mathrm{L}$ \\
\hline Bradyellopsis sp. & 1 & 15 & 0 & 1 & 5 & 2 & 14 & 10 & 6 & 3 & 42 & 11 \\
\hline Longipedia sp. & 395 & 381 & 422 & 387 & 647 & 514 & 110 & 10 & 13 & 2 & 94 & 0 \\
\hline Rhizothrix sp. & 0 & 52 & 0 & 0 & 26 & 0 & 0 & 21 & 0 & 1 & 10 & 0 \\
\hline
\end{tabular}


Table 4. Character states and predicted behavior of 3 species, showing that those of Bradyellopsis sp. matched the pattern for emergers and those of Rhizothrix sp. matched that for non-emergers (Table 1). P2-P4 end segs = number of segments in the endopods of pereiopods $2-4$ respectively. $\mathrm{P} 2-\mathrm{P} 4$ exp setae $=$ number of setae and spines on the distal exopod segments of pereiopods 2-4 respectively

\begin{tabular}{|lccccccc|}
\hline Species & $\begin{array}{c}\text { P2 } \\
\text { end } \\
\text { segs }\end{array}$ & $\begin{array}{c}\text { P3 } \\
\text { end } \\
\text { segs }\end{array}$ & $\begin{array}{c}\text { P4 } \\
\text { end } \\
\text { segs }\end{array}$ & $\begin{array}{c}\text { P2 } \\
\text { exp } \\
\text { setae }\end{array}$ & $\begin{array}{c}\text { P3 } \\
\text { exp } \\
\text { setae }\end{array}$ & $\begin{array}{c}\text { P4 } \\
\text { exp }\end{array}$ & $\begin{array}{c}\text { Predicted } \\
\text { behavior }\end{array}$ \\
\hline Bradyellopsis sp. & 3 & 3 & 3 & 8 & 8 & 8 & Emerger \\
Longipedia sp. & 3 & 3 & 3 & 6 & 6 & 5 & No prediction \\
Rhizothrix sp. & 2 & 2 & 2 & 4 & 4 & 4 & Non-emerger \\
\hline
\end{tabular}

\section{DISCUSSION}

Inspection of Table 1 reveals that the species we classified as emergers or non-emergers were not grouped taxonomically. In particular, emergence occurred in distantly related families (Ambunguipedidae, Ectinosomatidae, Thalestridae), raising the possibility that it evolved more than once. Because species of the Ectinosomatidae dominated the list of emergers, the behavior might be particularly common in this family.

Emergers did prove to share the characteristics of good swimmers. The only variation within the group was that some species had 7 rather than 8 setae on the terminal segments of pereiopods 3 or 4 (Table 1 ). We inferred therefore that all members were adapted to be swimmers to essentially the same degree, despite the taxonomic and therefore evolutionary heterogeneity of the group. This conclusion is consistent with the concept of Lebensformtypen (Remane 1952, Noodt 1971). The emergers also had relatively large cephalosome area (Tables $1 \& 2$ ), but the adaptive significance of this feature was not clear.

The non-emergers also shared morphological features. Their endopods had fewer than 3 segments on pereiopods $2-4$, and their exopods had 4 or fewer setae on the terminal segments of pereiopods 2-4 (Table 1 , Fig. 1). These features are similar to those of species living in the sediment that move by crawling or burrowing (e.g. Cylindropsyllidae, Paramesochridae) (Noodt 1971). The endopods of pereiopods 2-4 in such species often have fewer than 3 segments, and the terminal segments of the exopods of pereiopods $2-4$ have fewer than 7 setae (see Lang 1948, his plates 347-350 and 476-477, Fig. 1). That the morphology of the endopods of pereiopods 2-4 of the non-emergers approximated those of species known to live in the sediment suggests that non-emergers are less effective swimmers than emergers and are better adapted for life in the seabed. Our results are parallel with those of Nilsson et al. (2000), who found morphological differences between migrating (i.e. emerging) and nonmigrating oligochaetes.

We found a set of morphological characters that distinguished 6 emerger species from 2 non-emerger species. Although this result was promising, it required testing. As a first step, we examined the morphology of 3 species that were not among the 8 species considered above. We used the distribution of their abundance among base trap, leg trap, and sediment samples to infer their behavior, then predicted their behavior using our characters. Our prediction for 2 of the species was unambiguous and correct. The situation for Longipedia was more complex. The segmentation of the endopods of its pereiopods 2-4 matched that of the emergers, but the number of terminal setae on the exopods of pereiopods 2-4 did not. Because the terminal-seta character states did not match those of either group, we could not make a prediction. Because its abundance distribution among our samples was that of an emerger, and it has been reported from the near-bottom plankton (Huys et al. 1996), we concluded that it was an emerger, and that our hypothesis should be modified to state that emergers can have as few as 5 terminal setae on the exopods of pereiopods $2-4$.

We conclude that certain morphological characteristics unite the emergers we have studied, and different characteristics unite the non-emergers. If these results could be extended to other species and other locations, the characteristics would be useful for inferring emergence behavior in the absence of behavioral information and for correcting classifications based on trap data. Any common characteristics among emergers could also serve as foci for investigations of the ecology and evolution of the behavior.

Earlier, we raised the possibility that Bell et al.'s (1987) inferences about the emergence behavior of the species they examined was affected by their technique (see 'Introduction'). They identified species of Ectinosoma, Longipedia, Metis, Paradactylopodia, and Zausodes as emergers. In our material, Metis and Zausodes were too rare to study, but we found a species of Ectinosoma, a species of cf. Dactylopodia (which is closely related to Paradactylopodia; Huys et al. 1996), and a species of Longipedia to be emergers. The coherence between our results and those of Bell et al. (1987) suggests that the latter classified their emergers correctly, and adds weight to the notion that morphology will be efficacious in detecting emergent species. 
Acknowledgements. J. Winne and D. Oliff constructed the traps. S. Boa, S. C. Ertman, K. Suderman, and A. Wonnacott assisted in the field. The FSU Academic Diving Program provided equipment and training. S. Boa, L. Heiman, and K. Suderman helped in the laboratory. B. C. Hippolyte, A. Sorgo, M. Teasdale, A. B. Thistle, and K. Vopel made comments that improved the manuscript. The National Science Foundation (OCE-8911181) and the Office of Naval Research (N0001400-1-0007) supported the research. We are grateful for this kind help. This paper is contribution 1101 of the Florida State University Marine Laboratory.

\section{LITERATURE CITED}

Arlt G (1988) Temporal and spatial meiofauna fluctuations in an inlet of the southwest Baltic (Darss-Zingst Bodden Chain) with special reference to the Harpacticoida (Copepoda, Crustacea). Int Rev Gesamten Hydrobiol 73: 297-308

Armonies W (1988) Physical factors influencing active emergence of meiofauna from boreal intertidal sediments. Mar Ecol Prog Ser 49:277-286

Armonies W (1989) Meiofaunal emergence from intertidal sediment measured in the field: significant contribution to nocturnal plankton biomass in shallow waters. Helgol Meeresunters 43:29-43

Bell SS, Walters K, Hall MO (1987) Habitat utilization by harpacticoid copepods: a morphometric approach. Mar Ecol Prog Ser 35:59-64

Buffan-Dubau E, Castel J (1996) Diel and seasonal vertical distribution of meiobenthic copepods in muddy sediments of a eutrophic lagoon (fishponds of Arcachon Bay). Hydrobiologia 329:69-78

Fleeger JW, Chandler GT, Fitzhugh GR, Phillips FE (1984) Effects of tidal currents on meiofauna densities in vegetated salt marsh sediments. Mar Ecol Prog Ser 19:49-53

Fuller CM, Butman CA (1988) A simple technique for finescale, vertical sectioning of fresh sediment cores. J Sediment Petrol 58:763-768

Hicks GRF (1986) Distribution and behaviour of meiofaunal copepods inside and outside seagrass beds. Mar Ecol Prog Ser 31:159-170

Hicks GRF, Coull BC (1983) The ecology of marine meioben-

Editorial responsibility: Kenneth Heck (Contributing Editor), Dauphin Island, Alabama, USA thic harpacticoid copepods. Oceanogr Mar Biol Annu Rev 21:67-175

Huys R, Boxshall GA (1991) Copepod evolution. The Ray Society, London

Huys R, Gee JM, Moore CG, Hamond R (1996) Marine and brackish water harpacticoid copepods, part 1. Synopses of the British fauna (new series) no. 51. Field Studies Council, Shrewsbury

Lang K (1948) Monographie der Harpacticiden. Nordiska Bokhandeln, Stockholm

Marcus NH, Boero F (1998) Minireview: the importance of bentho-pelagic coupling and the forgotten role of life cycles in coastal aquatic systems. Limnol Oceanogr 43: $763-768$

Mees J, Jones MB (1997) The hyperbenthos. Oceanogr Mar Biol Annu Rev 35:221-255

Nilsson PG, Levinton JS, Kurdziel JP (2000) Migration of a marine oligochaete: induction of dispersal and microhabitat choice. Mar Ecol Prog Ser 207:89-96

Noodt W (1971) Ecology of the Copepoda. Smithson Contrib Zool 76:97-102

Palmer MA (1988) Dispersal of marine meiofauna: a review and conceptual model explaining passive transport and active emergence with implications for recruitment. Mar Ecol Prog Ser 48:81-91

Pfannkuche O, Thiel H (1988) Sample processing. In: Higgins $\mathrm{RP}$, Thiel $\mathrm{H}$ (eds) Introduction to the study of meiofauna. Smithsonian Institution Press, Washington, DC, p 134-145

Remane A (1952) Die Besiedelung des Sandbodens im Meere und die Bedeutung der Lebensformtypen für die Ökologie. Zoologischer Anzeiger, Supplementband 16:327-359

Thistle D (2003) Harpacticoid copepod emergence at a shelf site in summer and winter: implications for hydrodynamic and mating hypotheses. Mar Ecol Prog Ser 248:177-185

Thistle D, Weatherly GL, Wonnacott A, Ertman SC (1995) Suspension by winter storms has an energetic cost for adult male benthic harpacticoid copepods at a shelf site. Mar Ecol Prog Ser 126:77-86

Walters K, Bell SS (1986) Diel patterns of active vertical migration in seagrass meiofauna. Mar Ecol Prog Ser 34: 95-103

Walters K, Bell SS (1994) Significance of copepod emergence to benthic, pelagic, and phytal linkages in a subtidal seagrass bed. Mar Ecol Prog Ser 108:237-249

Submitted: January 7, 2003; Accepted: September 19, 2003

Proofs received from author(s): January 12, 2004 